\title{
MULHERES, RELIGIÃO E PODER: ENSAIOS FEMINISTAS
}

GEBARA, Ivone. Mulheres, religião e poder: ensaios feministas. São Paulo: Terceira Via, 2017.

\section{Perla Cabral Duarte Doneda*}

Ivone Gebara é doutora em filosofia pela Universidade Católica de São Paulo e em Ciências Religiosas pela Universidade Católica de Louvain. Foi professora de filosofia e teologia no Instituto de Teologia de Recife durante o bispado de Hélder Câmara. É integrante da Associação de Teólogos do Terceiro Mundo, assessora de grupos e é convidada como docente por universidades no Brasil e no exterior. Entre 1995 e 1996 viveu em Bruxelas, obrigada pelo Vaticano que Ihe impôs dois anos de silêncio e seu traslado à Europa. É autora de diversos livros e artigos, publicados no Brasil e em diferentes países.

Nesta obra, Ivone Gebara (2017) caracteriza as feministas como mulheres de estirpe, uma vez que todas buscam a liberdade, o espaço e a valorização da mulher. Fato que causa rejeição aos principais lugares religiosos do cristianismo. Os feminismos em sua diversidade são parte da luta pelos direitos humanos, uma vez que tem olhar crítico dos espaços em que homens e mulheres ocupam. Questões como violência doméstica sexualidade, maternidade voluntária, liberdade sexual, controle da mortalidade, reivindicações culturais, políticas e sociais, fazem parte das reflexões e das ações feministas. "O feminismo teológico tem uma grande importância na transformação das culturas, na medida em que desobriga as mulheres de obedecerem à ordem estabelecida de certas crenças religiosas patriarcais" (p. 12). Em sua obra, busca demonstrar o quanto o poder estabelecido pela religião católica fortalece o papel das

* Mestranda do Programa de Pós-Graduação em Ciências da Religião da Universidade Metodista de São Paulo. Membro do Grupo de Estudos de Gênero e Religião Mandrágora/NETMAL. Bolsista CAPES/PROSUC. 
mulheres no espaço privado e garante a hegemonia masculina, como poder estabelecido, conforme as narrativas e os símbolos aplicados.

Em se tratando de partes importantes da sua obra, há um conceito bastante difundido, de que o lugar dos indivíduos estaria conformado a uma ordem divina. Deus teria determinado que a mulher, ao poder gerar vidas, se mantivesse na casa, para o cuidado da família. Teoria conhecida como lei natural, acaba por submeter a mulher à reprodução. As que se manifestam contrárias, são advertidas a voltar "ao lugar onde Deus as queria"; "baixar os olhos, cobrir a cabeça e obedecer aos seus senhores" (p. 15).

Essa perpetuação misógina não se aplica tão-somente ao cristianismo. Segundo Gebara, a cultura de dominação do feminino faz parte de muitas outras religiões, que delegam aos homens papéis de autoridade e mando. O século $X X$ é o tempo em que as mulheres tomam consciência feminina, como fenômeno cultural, social e político e se descobrem colonizadas, proletárias e inferiorizadas. "Nossos direitos se confrontam e se conflitam com os deveres impostos por Deus!" (p. 22). Na Igreja Católica, o papa Francisco reflete sobre os direitos da mulher, mas ainda não há mudanças; aborda gênero, como ideologia, reafirmando o desconhecimento da instituição para enfrentar o assunto. A igreja vê a mulher de forma abstrata e monolítica, proveniente do pensamento hierárquico, que resulta na falta de direitos às mulheres, gerando políticas retrógradas.

A visão de identidades sexuais fixas e biológicas, macho e fêmea, é a base das afirmações sobre as verdades a serem vividas, objetivando responder às inseguranças do mundo de hoje, ignorando-se completamente que "só existimos com vida diversificada e interdependente" ( $p$. 27). As mulheres são excluídas e demonizadas, especialmente à prática do aborto, "ama-se mais o feto, considerado no caso específico como um ser inocente quase desprovido de história, em contraposição à muIher, cuja história curta ou longa é considerada de menor valor" (p. 39). Contudo, a autora tenta demonstrar outra perspectiva de transcendência que se desenvolva na multiplicidade de novas interpretações simbólicas e de linguagens, saindo do lugar absoluto e exclusivo do masculino em direção ao outro. 
A diversidade é um fenômeno complexo, mas se rejeita o modelo único oferecido às mulheres, principalmente como sendo de vontade divina. A produção literária universitária tem contribuído para que muitas mulheres se percebam e repensem os códigos morais, e assim revisem a tão propagada vocação à maternidade, para romper os papéis e funções naturais, atribuídos às mulheres como determinantes pelas religiões cristãs. Há uma confusão semântica entre humildade e humilhação, que contribuem para a perpetuação da dominação sobre a mulher, nessa estrutura hierárquica de poder religioso, limitando os espaços de atuação da mulher. Para tanto, a teologia tradicional tece elogios à maternidade e ao valor em obedecer ao plano divino. Supervaloriza a maternidade e submete a mulher ao modelo único no papel social, tendo Maria, humilde serva, como modelo perfeito, a serviço do plano divino.

Deus é apresentado como aquele que tem olho grande, em referência àquele que tudo vê e tudo julga. Essas forças imaginárias escravizam e iludem, cujas interpretações feitas servem para manter o poder masculino e a estrutura hierárquica sobre controle. Até o momento, o cristianismo não conseguiu estabelecer uma simbologia igualitária entre os gêneros nas mais diferentes organizações. Contudo, mesmo as mulheres sendo soberanas em suas casas, continuam colonizadas sob essa estrutura de poder, que só seria alterada se o Deus de olho grande fosse substituído por um olhar misericordioso, que se relacionasse com a diversidade, na responsabilidade social e política, com acolhida no interior das igrejas.

Sonhar com espaços mais igualitários possibilitou perceber que os lugares ocupados pelas mulheres no interior da igreja, como: catequistas, como aquelas que limpam e arrumam a paróquia, são postos semelhantes ao do lar, e se encaixam à caridade religiosa, mas não são iguais aos espaços dos homens. A própria cultura do cristianismo perpetua a ideia do servir os outros e servir aos sacerdotes, pois estes são considerados representantes de Cristo. As mulheres sonham também em poder decidir por seus corpos, muitas vezes marcados pela violência e ignorados diante de um discurso abstrato da metafísica, de elaboração perfeita, de um Deus perfeito, que resignaria as mulheres a viverem essa construção de perfeição, elaborada pelos homens, que 
decidem tudo para todos, em especial para as mulheres. Por isso, feministas desejam construir uma visão mais plural de igreja, condizente com o tempo presente, buscando mudar as relações de poder, para alterar a dominação e a exclusão das mulheres. Para tanto, é necessário seguir a diversidade nas experiências dos indivíduos, dos corpos que se atualizam há séculos de literaturas. Isso configuraria a ressurreição dos novos tempos. A autora explicita que a ressurreição é no tempo presente, não no conceito metafísico, de que a felicidade vivida seria experimentada após a morte, o que gera consolação em vida e não ação para que a felicidade de todos seja aqui e agora. "Nesse sentido, a ressurreição é vitória sobre as forças da morte que nos habitam, mas não é isenção de sofrimento" (p. 107).

O ser humano se sente seguro quando pensa sua vida regida por forças superiores, isso lhe faz pensar que haverá ordem, e é a base da nossa fé religiosa. Essa conduta faz que nos distanciemos de nossa realidade, quando novos problemas se apresentam. Nisso, a Igreja Católica relega saída a Jesus Cristo, aos Santos, o que evolui absurdamente em resoluções a partir das crenças, até com reflexos na espera política. Deus é o sumo bem e nós, compreendidos pela teologia clássica, como imperfeitos e pequenos, cremos que pouco podemos realizar. Por isso, o bom e o perfeito pertencem a Deus, ou ao tempo da sociedade originária, onde tudo era bom, em contraposição, temos quem defenda que somos originariamente maus, sendo impossível mudar isso. Nessa relação de pensar o bem e o mal, se reflete a igualdade e a diferença, e justamente a "igualdade se instaura a partir de nossas diferenças" ( $p$. 150). Esse reclamo se instaura na religião Católica, cuja conduta configura injustiça de gênero, pois propaga e mantém a inferiorização da mulher, que na prática não ocupa os mesmos espaços que os homens ocupam, mesmo discursando que diante de Deus somos todos iguais. "Não pode haver uma teoria, uma doutrina, uma filosofia, uma crença religiosa na qual caibam todas as pessoas de forma absoluta. A diversidade da terra e dos ecossistemas é a condição de manutenção de sua própria vida. $O$ mesmo se pode dizer dos seres humanos e da busca de valores" (p. 152).

A teologia feminista se ateve diante disso, a debater, não exaustivamente sobre as Escrituras, como faz a teologia tradicional, mas sim 
na ênfase da vida cotidiana. Segundo a autora, é preciso então tocar nas crenças, nas tradições culturais e familiares se desejarmos não nos alienar, a fim de que não percamos a capacidade de dinamizar a História. Deus está misturado ao cotidiano, nos aspectos simples da vida, não tem leis estritas, nem dogmas, nem provas para a sua existência, nem formas específicas para obedecê-lo ou desobedecê-lo. Não pede cultos, nem oferendas nem sacrifícios. Ele está misturado aos sacrifícios vividos na vida e nas alegrias experimentadas. Assim, o Deus das mulheres é aquele de nossa experiência, da intimidade cotidiana, das poucas palavras para expressá-lo. No entanto, há ainda muitas mulheres seduzidas pelas propostas pregadas nos templos, poucas se atrevem a pensar diferente, o que só reforça a dominação dos templos, e o poder sobre nossos corpos e nossa sexualidade.

Nessa perspectiva, Gebara apresenta o poder em sete partes, aludindo aos sete pecados capitais, e demonstra como a religião exerce o poder social e de controle, até na política. O primeiro deles é o poder de sentido: a vida se desdobra com muito sofrimento, isso seria a expressão de uma vontade maior, superior, de uma vontade boa, poderosa, que lhe cabe aceitar as contradições; é um poder que conforma a pessoa com sua sorte infeliz. O segundo é o poder do limite: se refere a controlar os impulsos expansionistas, a vontade de dominar os outros, os desejos de posse ilimitado de bens, até a capacidade de eliminar os outros, pois tudo está na vontade de Deus, limitando os nossos poderes. O terceiro é o poder da segurança: o medo é um sentimento constante na vida humana, buscar por segurança é perfeitamente normal. A Igreja Católica oferece uma infinidade de Santos, medalhas, orações e devoções religiosas, bem como, a crença em um Deus que segura a nossa mão. O quarto é o poder organizador da vida: que se estabelece conforme momentos importantes da vida das pessoas, a começar por festas próprias do cristianismo. A força do calendário cristão, católico, é de fato uma imensa influência até mesmo no trabalho, no repouso, nos hábitos alimentares, nas crenças entre vida e morte, com prêmios ou castigos na outra vida. O quinto é o poder do consolo e do perdão: consiste em mostrar que até Deus, Nossa Senhora e os Santos se condoem com o seu sofrimento, ou situação. Deus consola o seu povo. No Novo Testa- 
mento, até o Espírito Santo aparece como consolador. Essa ordem, de consolar, surge como feminina, pois são as mulheres que consolam as famílias enlutadas, em hospitais, presídios, asilos. O sexto é o poder da celebração simbólica de vida: está implicitamente ligado ao ser humano, somos seres de festa, faz parte da estrutura ontológica. Celebramos vários momentos da vida, isso orienta, marca o tempo e o espaço das coisas, são também as mulheres que organizam as celebrações da vida. O sétimo e último é o poder de influir nos rumos e nas decisões históricas: está concentrado na capacidade de inferir junto às decisões de Estado, que se diz laico, mas suas bases são absolutamente repletas de referências religiosas, influenciando de forma significativa o rumo dos cidadãos. Aos desafios presentes, nessa ordem, deveriam participar as teólogas feministas, incluindo assim as mulheres nas instituições, tanto no nível simbólico quanto no nível do exercício público da autoridade religiosa, cuja finalidade seria rever, de forma mais igualitária.

Para Gebara, há que se resolver a complexa realidade e não será imitando modelos fixos que isso ocorrerá, o que abre espaço para a produção feminista. É preciso ouvir a fala alheia, portanto a Teologia Cristã, se deseja ser fiel ao Evangelho, precisa ter essa postura ética, diante da história das mulheres e dos homens. A transgressão, a desobediência passam a ser a nova ordem social política e religiosa dominante. "Transgredir e desobedecer ordens injustas são ações de fortalecimento e respeito à vida" (p. 191). O dado biológico não pode ser uma prisão para a mulher, bem como, pensar que o cristianismo, simbolicamente, substituiu a Mãe Terra, originária, pelo Pai Criador. Com isso, não se pretende substituição, "não buscamos novos reducionismos, mas apenas sair de uma absolutização que provocou inúmeros desequilíbrios e injustiças" (p. 193).

"Rejeitamos a Igreja como uma instituição de controle e de vigilância a serviço da realização da vontade de Deus" (p. 194). No entanto, sugere que deve se pensar na transgressão a partir do conceito queer a uma teologia indecente, cuja proposta foi desenvolvida por Marcella Althaus-Reid," como nova busca para as complexidades humanas, que

ALTHAUS-REID, Marcela. Teologia Indecente. Barcelona: Ediciones Bellaterra, 2005. 
soam estranhas na teologia tradicional decente. Queer parte da ideia daquele que é indesejado, diferente, excluído, sujo, rejeitado, marginalizado, o que não tem identidade fixa. A ideia queer transcenderia a normatividade, romperia ideologias identitárias, modelos de perfeição preestabelecidos.

De toda forma, a proposta de Gebara nessa obra é bastante ousada e atual, uma vez que descontrói as posições de Deus entre os homens e as mulheres, entre o indivíduo e as instituições, negando a hierarquia predominante e masculina, objetivando reorganizar a vida das pessoas a partir delas mesmas, das suas realidades concretas, sem que se anule a existência de um Deus, ou uma Deusa, mas que isso seja afirmado e vivido nas experiências cotidianas em busca de uma maior felicidade para todos e todas, aqui e agora. A vida vem antes das crenças!

Submetida em: 22-11-2018

Aceita em: 6-12-2018 